\section{Strange Method of Crossing a Torrent}

HAVING seen something very like, if not quite identical with, the following in the Himalayas, I am anxious to know if it is not a conimoner device under similar conditions than is generally supposed everywhere. The story occurs in Gerard Boote's (Doctor of Physick) "Inland's Natural History," p. 59, and is related on the authority of "one Theophilus Buckworth, a Bishop of Dromore," in whose presence the feat was performed. His description of it runs as follows. After mentioning that the brook or river "that passeth by that town was greatly risen," he adds that "A country fellow who was travelling that way having stayed three days in hope that the water would fall, and seeing that the rain continued, grew impatient, and resolved to pass the brook whatever the danger was, but to do it with the less peril and the more steadiness he took a great heavy stone upon his shoulders, whose weight, giving him some firmness against the violence of the water, he passed the same without harm and came safe to the other side, to the wonderment of many people who had been looking on and given him up for a lost person."

Warrington

W. CURRAN

\section{Intellect in Brutes}

NoT having seen any reference to Cowper's famous hares in any of the notices under this heading that have appeared in NATURE, I am induced to refer to them, the more so as the creature is rarely credited with much gratitude or intelligence. My information is from Tegg's edition of "The Life and Works of William Cowper," p. 633. Describing, at this place, the capers of his favourite hare named "Puss," who "would suffer me to take him up and to carry him about in my own arms," our poet adds that "he was ill three days, during which time I nursed him, kept him apart from his fellows, . . . . and by constant care, \&c., restored him to perfect health. No creature could be more grateful than my patient after his recovery, a sentiment which he most significantly expressed by licking my hand, first the back of it, then the palm, then every finger separately, then between all the fingers, as if anxious to leave no part of it unsaluted; a ceremony which he never performed but once again upon a similar occasion. Finding him extremely tractable, I made it my custom to carry him always after breakfast into the garden..... I had not long habituated him to this taste of liberty before he began to be impatient for the return of the time when he might enjoy it. He would invite me to the garden by drumming upon my knee and by a look of such expression as it was not possible to misinterpret. If this rhetoric did not immediately succeed, he would take the skirt of my coat between his teeth and pull it with all his force." $\mathrm{He}$ "seemed to be happier in human society than when shut up with his natural companions," and if these traits do not betoken something more than instinct, it is hard to say where this ends and intellect begins.

Warrington

W. CURRAN

\section{Anchor-Ice}

HAving lately read with much interest several letter3 to NATURE on the subject of the formation of anchor- or groundice, I beg leave to inform your readers that it forms here every season in the Rock Island rapids of the Upper Mississippi River; any one desirous of studying its mode of formation would here have a good opportunity. Some observations of mine upon this phenomenon may be found in vol. ii. of the Proceedings of the Davenport Academy of Natural Sciences, p. 349.

Davenport, Iowa, U.S., July ro

R. J. FArquharson

\section{Depraved Taste in Animals}

WHILE in Australia I kept at different times several koalasall taken young. Of these three were inordinately fond of tobacco in any form. They would chew and swallow the strong Victorian black tobacco with the greatest gusto, and one, to which I gave a foul clay pipe saturated with tobacco oil, devoured the whole of the stem. Sitting on the nape of my neck, his usual place when I was writing or reading in the evening, "Ka-koo" would frequently stretch out one hand, take the pipe from my mouth, and berin to chew it if not promptly interfered with. During the day he passed most of his time rolled up on the rafters of the roof, bush houses being devoid of a ceiling, and on hearing the clinking of glasses, which betokened the preparation of the evening glass of grog, hurried down from his perch to receive his modest share of whisky and water. If a spoon were dipped in the raw spirit and given to him, he would take it in both his paws and lick it dry with manifest appreciation, and could only be pretented from making a raid upon every glass on the table by being tied with a handkerchief by the leg to the back of a chair. No ill effects ever followed these indulgences.

ARTHUR NICOLS

\section{THUNDERSTORMS 1}

WHEN I was asked to give this lecture $I$ was also asked to give a short list of subjects from which your directors might select what they thought most fit. I named three. Regarded from the scientific point of view, one of them was to be considered as fully understood in principle, and requiring only additional experimental data to make it complete. This was the Conduction of Heat in Solids. Another was to a certain extent scientifically understood, but its theory was, and still is, in need of extended mathematical development. This was the popular scientific toy, the Radiometer. The third was, and remains, scarcely understood at all. Of course it was at once selected for to-night. I might have foreseen that it would be. You may well ask, then, why I am here. What can I say about a subject which I assert to be scarcely understood at all? A few years ago no qualified physicist would have ventured an opinion as to the nature of electricity. Magnetism had been (to a certain extent, at least) cleared up by an assumption that it depended on electric currents; and from Örsted and Ampère to Faraday and Thomson, a host of brilliant experimenters and mathematicians had grouped together in mutual interdependence the various branches of electrodynamics. But still the fundamental question remained unsolved, What is electricity? I remember Sir W. Thomson, eighteen years ago, saying to me, "Tell me what electricity is, and I'll tell you everything else." Well, strange as it may appear to you, I may now call upon him to fulfil his promise. And for good reason, as you shall see.

Science and Scotland have lately lost in Clerk-Maxwell one of their greatest sons. He was, however, much better known to science than to Scotland. One grand object which he kept before him through his whole scientific life was to reduce electric and magnetic phenomena to mere stresses and motions of the ethereal jelly. And there can be little doubt that he has securely laid the foundation of an electric theory-like the undulatory theory of light admirably simple in its fundamental assumptions, but, like it, requiring for its full development the utmost resources of mathematical analysis. It cannot but seem strange to the majority of you to be told that we know probably as much about the secret mechanism of electricity as we do about that of light, and that it is more than exceedingly probable that a ray of light is propagated by electric and electromagnetic disturbances. It is one of the most remarkable advances made during this century.

But to know what electricity is, does not neccssarily guide us in the least degree to a notion of its source in any particular instance. We might ${ }_{3}^{\text {kn }}$ now quite well what is electricity and yet be, as I told you at starting we are, almost entirely uncertain of the exact source of atmospheric electricity.

To come to my special subject. I am not going to try to describe a thunderstorm. First, because I am certain that I could not do it without running the risk of overdoing it, and thus becoming sensational instead of scientific; and secondly, because the phenomenon must be quite familiar, except perhaps in some of its more singular details, to every one of you.

Science has to deal with magnitudes which are very much larger or smaller than those which such words as huge, enormous, tiny, or minute are capable of expressing. And though an electric spark, even from our most x Abstract of a lecture, delivered in the City Hall, Glasgow, by Prof. Tait. 